\title{
Analysis of Olympic Games (Rio de Janeiro, 2016) participants' individual competition compositions in calisthenics
}

\author{
Kovalenko Y.O., Boloban V.N. \\ National University of Physical Education and Sport of Ukraine
}

\begin{abstract}
Purpose:

to show structural elements of individual competition compositions of female gymnasts - Olympic Games (Rio de Janeiro, 2016) finalists.

Material: $\quad$ video-computer analysis of Olympic Games participants' exercises; analysis of competition records.

Results: $\quad$ it was found that female gymnasts' individual fitness is characterized by the following: correlation of time for Body Difficulty elements' fulfillment and Apparatus Difficulty elements. It is expressed in quickness of preparation to element's fulfillment; in logical and technically accurate transition from element to element. Accent on static elements permitted for sportswomen to reduce movements' area. With dynamic style of elements' fulfillment movements' area was larger.

Conclusions: Most female gymnasts demonstrated natural elements' distribution in compositions. Space movements opened the best views of static and dynamic elements' fulfillment that was an evidence of female gymnasts' high sportsmanship.

Keywords: female gymnast, individual exercise, composition, apparatus, construction, coordination, space, time, result.
\end{abstract}

\section{Introduction}

Calisthenics competitions at Olympic Games (OG) have been becoming traditional recent time. During Olympic cycle (2013-2016) competition rules were substantially changed [16]. Requirements to composition, difficulty of exercises and performance skillfulness came to the fore. Referees shall assess choreography, entertaining potential, exercises' difficulty and spacetime movements on site. With it, quantity of body elements was shortened in favor of tracks and apparatus's manipulation. Sportswomen, who harmoniously combine technically correct fulfillment of Body Difficulty and Apparatus Difficulty elements with artistry of competition compositions, are assessed highly [11]. Artistry is motor functioning at high performance level and art taste [3, 7, 17-20]. In gymnastic artistry is understood as perfectness, completeness, expressiveness, elegance, uniqueness of movements and exercise in the whole [1]. Mistakes of artistry are: deficit of lightness, confidence, elegance; awkward movements, incomplete, tensed performance. In calisthenics artistry is an important element of performing mastery. It is a component of experts' final evaluation of female gymnasts' competition compositions [4].

In the researches, fulfilled two years, before Olympic Games 2016 [5], there were registered technical mistakes in fulfillment space-time indicators of individual exercises' structural elements. It was found that space time movements in the structure of the fulfilled individual exercises are the basis of competition compositions [13]. Results of such researches proved validity of IFG (International Federation of Gymnastic) actions, directed at compositions' perfection, based on increased requirements to difficulty and performing mastery. Composition picture is created by the following: correct and logical grouping of elements and their combinations on site; accurate space movements of a gymnast. Time

(c) Kovalenko Y.O., Boloban V.N., 2017

doi:10.15561/18189172.2017.0303 characteristics permit to evaluate gymnast's ability to fulfill elements of competition compositions. Such evaluation depends on quickness of preparation for elements and directly time of elements' fulfillment.

Analysis of structural elements of female gymnasts - Olympic Games participants' individual competition compositions is conditioned by need in determination of key structural elements, owing to which female gymnasts became finalists.

The purpose of the research is to show structural elements of individual competition compositions of female gymnasts - Olympic Games (Rio de Janeiro, 2016) finalists.

The tasks of the research:

1. Basing on analysis of special literature to study theoretical base of competition compositions' individual exercises in calisthenics.

2. To study space-time structural elements of individual competition compositions of female gymnasts Olympic Games (Rio de Janeiro, 2016) finalists.

\section{Material and methods}

Participants: we fulfilled video-computer analysis of 5 female gymnasts' performances. All they were the finalists of calisthenics Olympic Games 2016 ( 4 kinds of individual multiathlon). Competition compositions were performed by female gymnasts from: Azerbaijan (AZE), Bulgaria (BUL), Byelorussia (BLR), Russian Federation (RUS), Ukraine (UKR) (see table).

Organization of the research: video-computer analysis of Olympic Games participants' exercises and analysis of competition records were carried out. The purpose of video-analysis was study of space-time structural elements of individual compositions.

In the process of analysis we considered the following structural elements:

1. Time, spent for body difficulty elements' fulfillment;

2. Time, spent for Apparatus Difficulty elements' 
fulfillment:

- Dance tracks $(\mathrm{S} \rightarrow \mathrm{r})$;

- Elements of sportsmanship (M);

- Elements of risk (R);

3. Space movements of female gymnasts on site.

Statistical analysis: the materials of the research were processed with the help of mathematical statistic methods (Excel, Statistika) [8].

\section{Results}

Analysis of video records of the strongest female gymnasts' individual exercises permitted to specify duration of compositions. In average it was 1,30 $\pm 0,03^{\prime \prime}$. It witnesses about absence of rough technical mistakes, connected with exceeding the time of competitions. Final results see in table below.

It was found that the most time for body difficulty elements was spent by Bulgarian gymnast (BUL) Neviana Vladinova. It was conditioned by fulfillment of jump combination, consisted first of single jump jete en tournant with torso backward arching and then of two jumps jete en tournant. When fulfilling jete en tournant in ringв the gymnast realized throw in static position and waited for apparatus after throw (that was a technical mistake). In exercise with hoop Neviana Vladinova demonstrated interesting elements of sportsmanship and elements of risk. She accented on throwing of apparatus by legs and other parts of body without visual control. It made composition more expressive and difficult. Yana Kudryavtseva, female gymnast from Russian Federation (RUS) showed the least time, spent for body difficulty elements. She demonstrated the varied use of apparatus. In her performance sportsmanship elements were integral with dance tracks and risk elements. Fulfillment of body

Table. Final results of Olympic Games 2016 finalists (calisthenics individual multiathlon) ( $n=10)$

\begin{tabular}{|c|c|c|c|c|c|c|c|c|c|}
\hline \multirow{3}{*}{$\begin{array}{l}\text { № } \\
\\
1\end{array}$} & \multirow{3}{*}{$\begin{array}{l}\text { Name and surname } \\
\text { of female gymnast, } \\
\text { country, place and } \\
\text { sum of points } \\
\text { Margarita Mamun } \\
\text { RUS } \\
\text { Place:1 }(76,483)\end{array}$} & \multicolumn{8}{|c|}{ Kind of individual multiathlon } \\
\hline & & $D=9,55$ & \multirow[t]{2}{*}{$E=9,5$} & $D=9,65$ & \multirow[t]{2}{*}{$E=9,5$} & $D=9,55$ & \multirow[t]{2}{*}{$E=9,5$} & $D=9,7$ & \multirow[t]{2}{*}{$E=9,55$} \\
\hline & & $\mathrm{Sc}=19,050(2)$ & & $\mathrm{Sc}=19,150(2)$ & & $\mathrm{Sc}=19,05(1)$ & & $\mathrm{Sc}=19,25(1)$ & \\
\hline \multirow[t]{2}{*}{2} & $\begin{array}{l}\text { Marina Durunda } \\
\text { AZE }\end{array}$ & $D=8,65$ & $E=8,3$ & $\mathrm{D}=8,775$ & $E=8,766$ & $D=8,95$ & $E=8,766$ & $D=8,775$ & $E=8,76$ \\
\hline & Place:9 $(69,748)$ & \multicolumn{2}{|c|}{$\mathrm{Sc}=16,95(10)$} & \multicolumn{2}{|c|}{$\mathrm{Sc}=17,541(9)$} & \multicolumn{2}{|c|}{$\mathrm{Sc}=17,716(6)$} & \multicolumn{2}{|c|}{$S c=17,541(6)$} \\
\hline \multirow[t]{2}{*}{3} & $\begin{array}{l}\text { Yana Kudryavtseva } \\
\text { RUS }\end{array}$ & $D=9,7$ & $E=9,525$ & $D=9,65$ & $E=9,6$ & $D=8,7$ & $E=9,183$ & $D=9,65$ & $E=9,6$ \\
\hline & Place:2 $(75,608)$ & \multicolumn{2}{|c|}{$S c=19,225(1)$} & \multicolumn{2}{|c|}{$\mathrm{Sc}=19,25(1)$} & \multicolumn{2}{|c|}{$\mathrm{Sc}=17,883(5)$} & \multicolumn{2}{|c|}{$\mathrm{Sc}=19,25(1)$} \\
\hline \multirow[t]{2}{*}{4} & $\begin{array}{l}\text { Katsiaryna Halkina } \\
\text { BLR }\end{array}$ & $D=9,0$ & $E=8,966$ & $D=9,00$ & $E=8,966$ & $D=8,75$ & $E=8,9$ & $D=8,65$ & $E=8,7$ \\
\hline & Place:6 $(70,932)$ & \multicolumn{2}{|c|}{$\mathrm{Sc}=17,966(6)$} & \multicolumn{2}{|c|}{$\mathrm{Sc}=17,966(6)$} & \multicolumn{2}{|c|}{$\mathrm{Sc}=17,65(8)$} & \multicolumn{2}{|c|}{$\mathrm{Sc}=17,35(7)$} \\
\hline \multirow[t]{2}{*}{5} & $\begin{array}{l}\text { Kseniya Mousta- } \\
\text { faeva }\end{array}$ & $D=8,9$ & $E=8,8$ & $D=8,65$ & $E=8,233$ & $D=8,65$ & $E=8,266$ & $D=8,175$ & $E=8,56$ \\
\hline & $\begin{array}{l}\text { FRA } \\
\text { Place:10 }(68,240)\end{array}$ & \multicolumn{2}{|c|}{$\mathrm{Sc}=17,7(8)$} & \multicolumn{2}{|c|}{$\mathrm{Sc}=16,833(10)$} & \multicolumn{2}{|c|}{$\mathrm{Sc}=16,916(9)$} & $S c=16,7$ & (10) \\
\hline 6 & $\begin{array}{l}\text { Melitina Staniouta } \\
\text { BLR }\end{array}$ & $D=9,0$ & $E=9,2$ & $D=9,05$ & $E=9,2$ & $D=8,4$ & $E=8,233$ & $\mathrm{D}=8,85$ & $E=9,2$ \\
\hline & Place:5 $(71,133)$ & $\mathrm{Sc}=18,2$ & & $\mathrm{Sc}=18,2$ & & $\mathrm{Sc}=16,6$ & $3(10)$ & $\mathrm{Sc}=18,0$ & \\
\hline 7 & $\begin{array}{l}\text { Carolina Rodriguez } \\
\text { ESP }\end{array}$ & $D=8,75$ & $E=8,866$ & $D=8,75$ & $E=8,933$ & $D=8,8$ & $E=8,9$ & $D=8,45$ & $E=8,5$ \\
\hline & Place:8 $(69,949)$ & $\mathrm{Sc}=17,6$ & $6(9)$ & $S c=17,6$ & & $S c=17,7$ & & $\mathrm{Sc}=16,9$ & \\
\hline 8 & $\begin{array}{l}\text { Son Yeon Jae } \\
\text { KOR }\end{array}$ & $D=9,15$ & $E=9,066$ & $D=9,2$ & $E=9,066$ & $D=9,2$ & $E=9,1$ & $D=9,15$ & $E=8,96$ \\
\hline & Place:4 $(72,898)$ & $\mathrm{Sc}=18,2$ & $6(3)$ & $\mathrm{Sc}=18,2$ & & $\mathrm{Sc}=18,3$ & & $\mathrm{Sc}=18,1$ & (4) \\
\hline 9 & $\begin{array}{l}\text { Ganna Rizatdinova } \\
\text { UKR }\end{array}$ & $D=9,1$ & $E=9,1$ & $D=9,25$ & $E=9,2$ & $D=9,25$ & $E=9,2$ & $D=9,25$ & $E=9,23$ \\
\hline & Place:3 $(73,583)$ & $S c=18,2$ & & $\mathrm{Sc}=18,4$ & & $\mathrm{Sc}=18,4$ & (2) & $S c=18,4$ & (3) \\
\hline 10 & $\begin{array}{l}\text { Neviana Vladinova } \\
\text { BUL }\end{array}$ & $D=9,05$ & $E=8,833$ & $D=9,05$ & $E=8,7$ & $D=9,15$ & $E=8,9$ & $D=8,55$ & $E=8,5$ \\
\hline & Place:7 $(70,733)$ & $\mathrm{Sc}=17,8$ & $3(7)$ & $\mathrm{Sc}=17,7$ & & $\mathrm{Sc}=18,0$ & (4) & $\mathrm{Sc}=17,0$ & \\
\hline
\end{tabular}

Notes: D - difficulty; E - performance; Sc - final points. 
difficulty elements and apparatus difficulty elements took fractions of seconds. It witnesses about perfect technical fitness (see fig. 1).

Effective space movements in hoop exercise were registered in female gymnasts of Russian Federation (RUS) and Ukraine (UKR). Gymnasts covered the largest moving area (distance, covered by female gymnast in fulfillment of exercise). Yana Kudryavtseva [silver prize winner of OG 2016, Russian Federation (RUS)] started exercise from fixed moment of balance. Then she fulfilled diagonal dance track, coming in central position for turn in attitude. Covering $50 \%$ of site by semi-circumference she fulfilled dance track. This track smoothly passed into jump with rotation. These actions were preparatory for realization of the most important diagonal element: element of sportsmanship Dive Split Leap with high throw of apparatus and catching it (in rotation) behind the back in jump.

Ganna Rizatdinova, [silver prize winner of $\mathrm{OG}$ 2016, Ukraine (UKR)] improved her space movements' indicators, comparing with previous researches in 2012-2015. She often moved on foreground in front of referees' group and fulfilled elements of body difficulty at the highest technical level. Combination of three jete en tournant was fulfilled circumferentially, with high amplitude and lightness (see fig. 2).

In exercise with ball the least time indicators were registered in gymnast from Republic of Byelorussia (BLR) Melitina Staniouta. She showed the highest degree of apparatus's manipulation. All sportsmanship elements were built on use of rolls, repulses, passes of apparatus.
The composition was completed by two sequential elements of sportsmanship. Risk element was fulfilled after rotating element - jump. This helped for gymnast to save time for additional throw of apparatus.

Azerbaijan (AZE) gymnast, Marina Durunda, in exercise with ball combined elements and kept balance not leaving support. Effective element of skillfulness (ball's repulse by chest) was realized in element Stag leap. Besides, 14" were spent for fulfillment of two rotations' combinations: rotating 7 pirouettes she earned high points in elements of body difficulty (see fig. 3).

In exercise with ball all female gymnasts shortened the time of space movements on site. Exclusion was only gymnast from Russian Federation (RUS) Yana Kudryavtseva. In her exercise there are diagonal, semicircumferential, vertical and horizontal movements in respect to referees' group. The least space movements were demonstrated by gymnast from Byelorussia (BLR) Melitina Staniouta. She covered site perimeter only one time that was minimal indicator among the studied compositions (see fig. 4).

In exercises with clubs time indicators did not change. To large extent it is characterized by technical and general fitness of female gymnasts. It permits to fulfill element without durable preparation and combine skillfulness and risk elements with elements of apparatus difficulty. Azerbaijan (AZE) gymnast demonstrated very high level. She fulfilled elements of body difficulty longer them al the rest. Many elements were completed by passing to acrobatic element that gives bonus of 0.1 point. Ganna Rizatdinova demonstrated maximal quantity of rotations

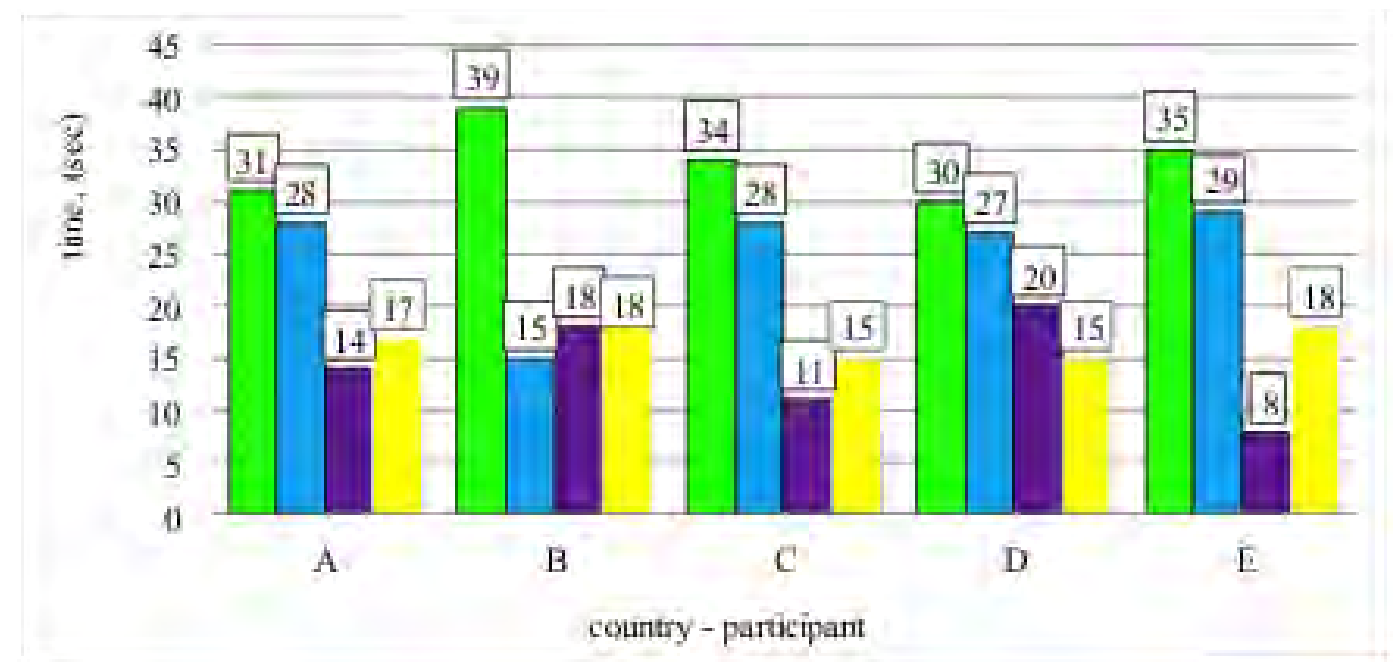

Fig. 1. Indicators of time, spent for fulfillment of individual compositions' with hoop structural elements, by female gymnasts from countries: A - AZE (Azerbaijan); B - BUL (Bulgaria); C - BLR (Republic of Byelorussia); D - RUS (Russian Federation); E - UKR (Ukraine);

Elements of body difficulty (BD);

Elements of apparatus difficulty (AD):

Dance tracks ( $\overrightarrow{\mathrm{W}} \overrightarrow{\mathrm{*}})$;

Elements of sportsmanship (M);

Elements of risk (R); 


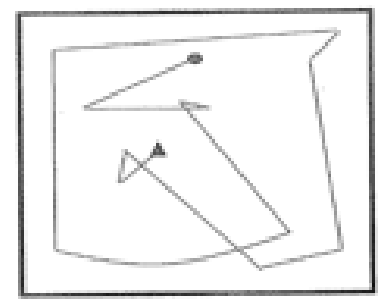

A

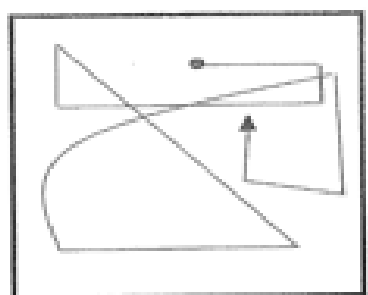

B

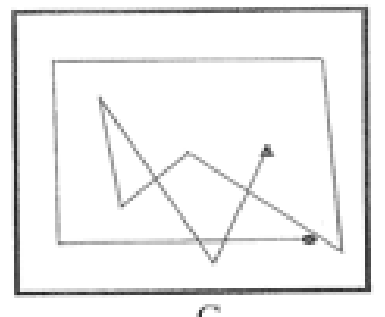

$\mathrm{C}$

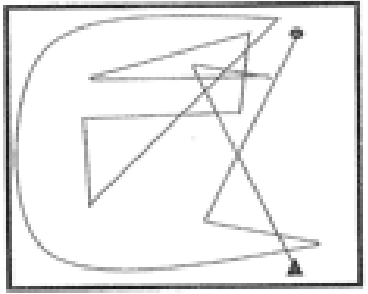

D

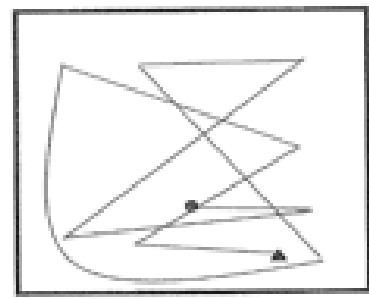

E

Fig. 2. Kinds of female gymnasts' movements on site in competition compositions with hoop: A - Hoop composition of Azerbaijan (AZE) gymnast; B - Hoop composition of Bulgaria (BUL) gymnast; (BUL); C Hoop composition of gymnast from Republic of Byelorussia (BLR); D - Hoop composition of gymnast from Russian Federation (RUS); E - Hoop composition of gymnast from Ukraine (UKR);

$\Delta$ - Beginning of exercise;

- End of exercise.

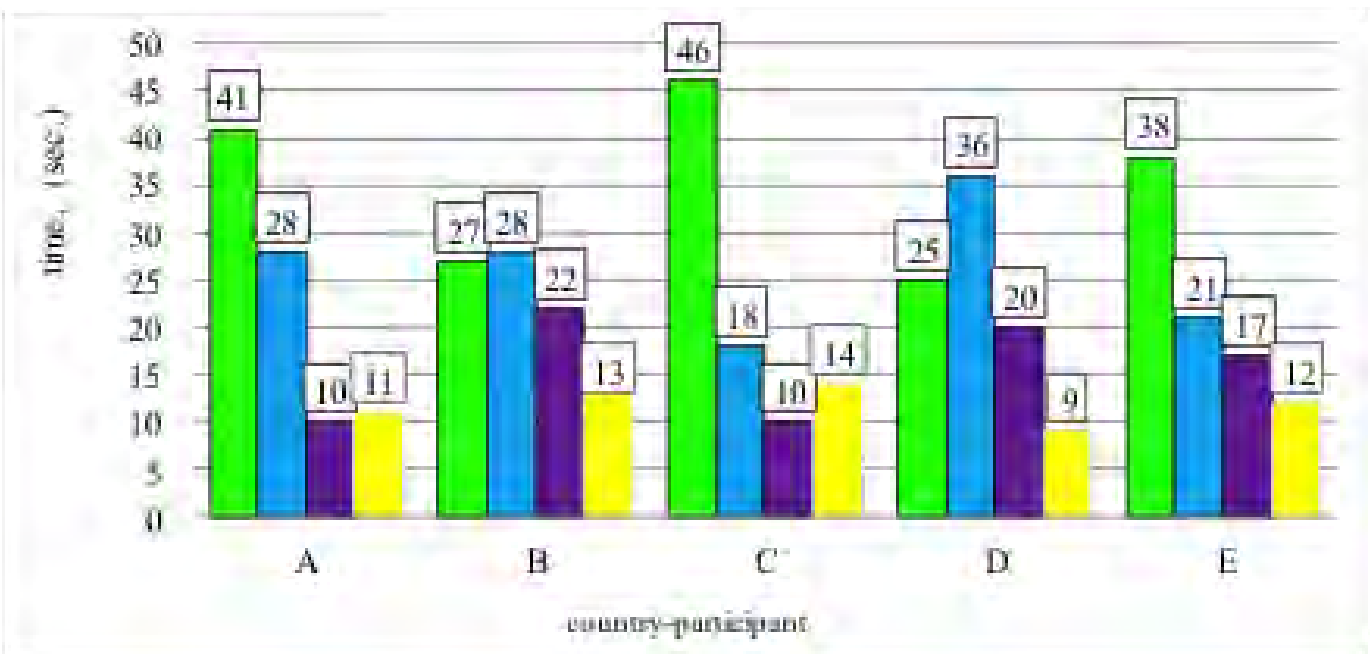

Fig. 3. Indicators of time, spent for fulfillment of individual compositions' with ball structural elements, by female gymnasts from countries: A - AZE (Azerbaijan); B - BUL (Bulgaria); C - BLR (Republic of Byelorussia); D - RUS (Russian Federation); E - UKR (Ukraine);

Elements of body difficulty (BD);

Elements of apparatus difficulty $(A D)$ :

$\square$ Dance tracks $(\mathrm{S} \overrightarrow{\mathrm{*}})$;

Elements of sportsmanship (M);

Elements of risk (R);

in pirouettes attitude, penche. With long fulfillment of exercise it brought positive effects: maximal assessment of body difficulty elements, expressiveness and prevailing over other gymnasts. In exercise one skillfulness element was registered (2") in combination with body difficulty element: balance. In this exercise accent was made on body difficulty elements as well as on dance tracks (3, 8 "' each and 1 of 11"). Competition rules dictate that track shall be registered if fulfilled at 8 " without technical mistakes (see fig. 5). 


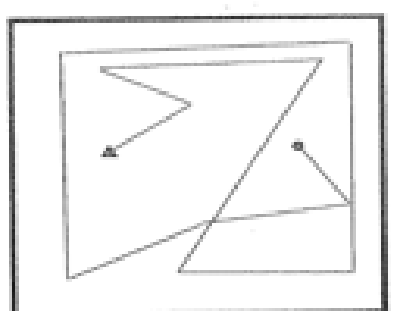

A

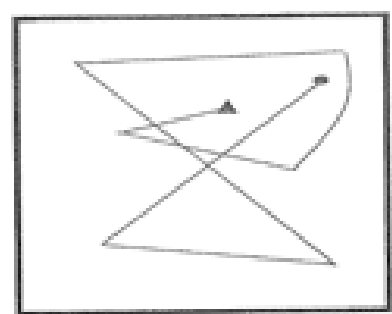

B

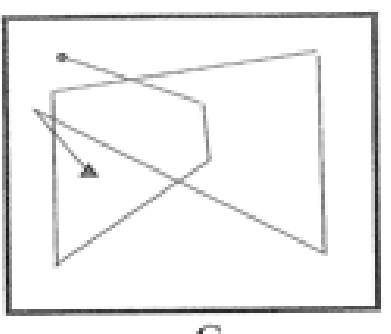

C

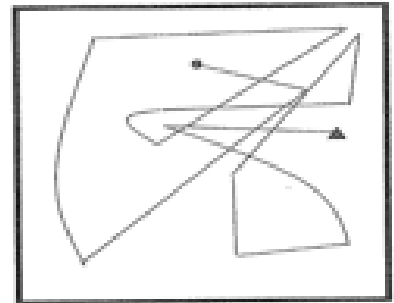

D

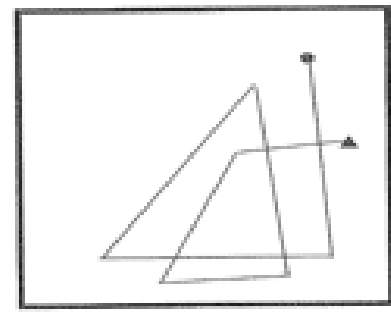

$\mathrm{E}$

Fig. 4. Kinds of female gymnasts' movements on site in competition compositions with ball: A -Ball composition of Azerbaijan (AZE) gymnast; B - Ball composition of Bulgaria (BUL) gymnast; (BUL); C - Ball composition of gymnast from Republic of Byelorussia (BLR); D - Ball composition of gymnast from Russian Federation (RUS); E - Ball composition of gymnast from Ukraine (UKR);

\section{$\boldsymbol{\Delta}$ - Beginning of exercise; \\ - End of exercise.}

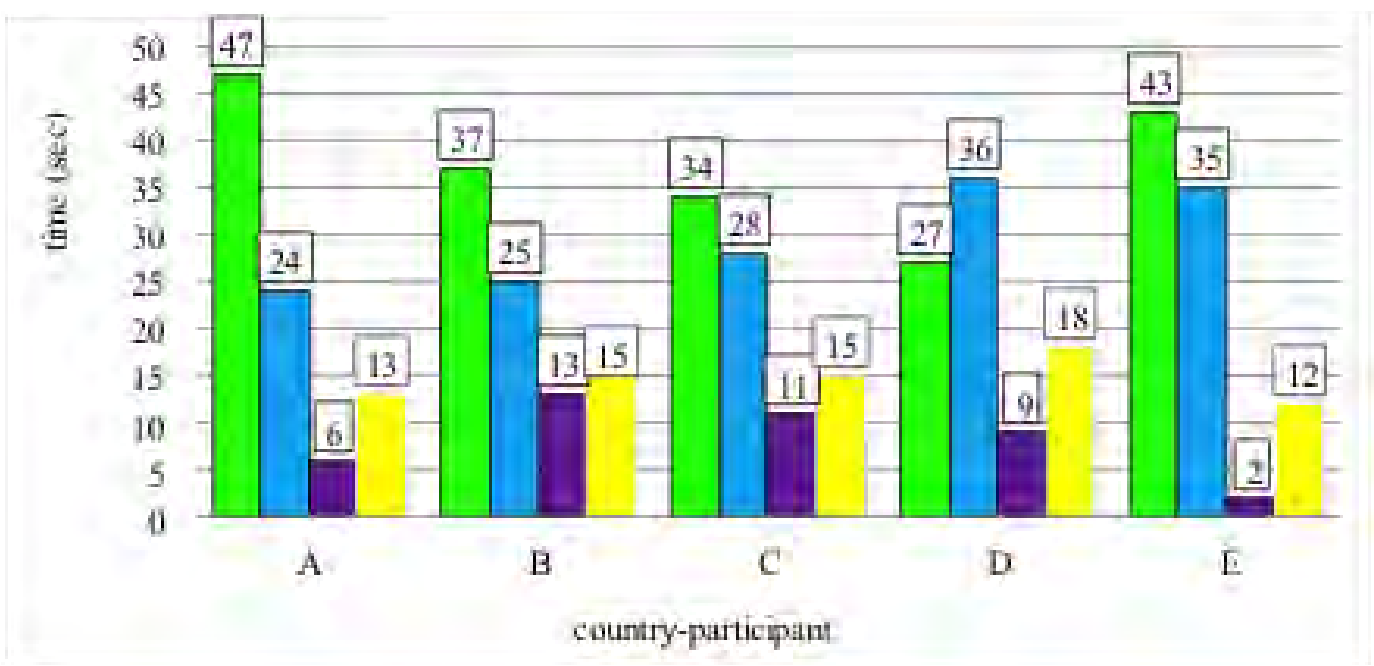

Fig. 5. Indicators of time, spent for fulfillment of individual compositions' with clubs structural elements, by female gymnasts from countries: A - AZE (Azerbaijan); B - BUL (Bulgaria); C - BLR (Republic of Byelorussia); D - RUS (Russian Federation); E - UKR (Ukraine);

$\square$ Elements of body difficulty (BD);

Elements of apparatus difficulty (AD):

$\square$ Dance tracks $(\mathrm{S} \overrightarrow{\mathrm{m}})$;

Elements of sportsmanship (M);

Elements of risk (R);

In space moving on site, gymnast from Ukraine (UKR) (musical accompaniment in performance of Michael Jackson) movement "zigzag" should be noted, which was possible to be watched in suite as well. Sharp turns and diagonal movements reflected the character of music. Exercise of Bulgarian (BUL) gymnast Neviana Vladinova had all kinds of changeover: diagonal, semicircumference. Besides, the gymnast moved vertically and horizontally in respect to ground jury. When fulfilling exercise with clubs, Neviana passed one circle of the 


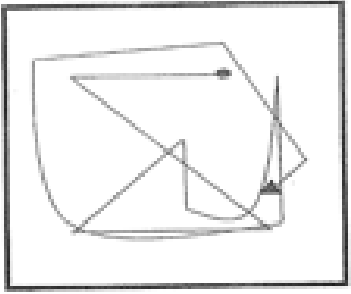

A

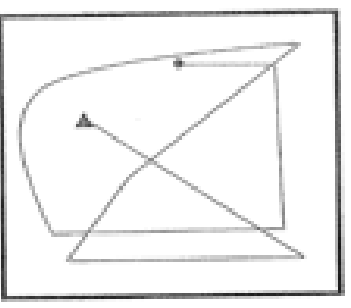

B

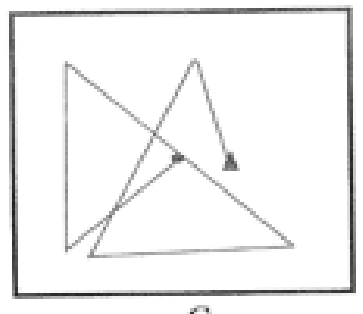

C

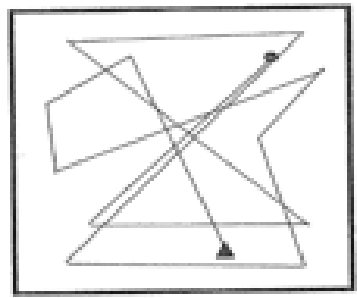

D

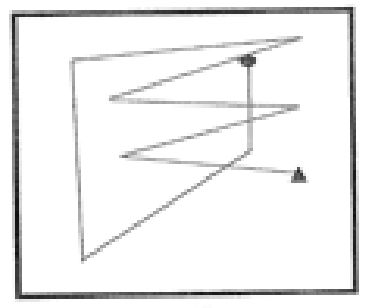

E

Fig. 6. Kinds of female gymnasts' movements on site in competition compositions with clubs: A - Club composition of Azerbaijan (AZE) gymnast; B - Club composition of Bulgaria (BUL) gymnast; (BUL); C - Club composition of gymnast from Republic of Byelorussia (BLR); D - Club composition of gymnast from Russian Federation (RUS); E - Club composition of gymnast from Ukraine (UKR);

\section{- Beginning of exercise; \\ - End of exercise.}

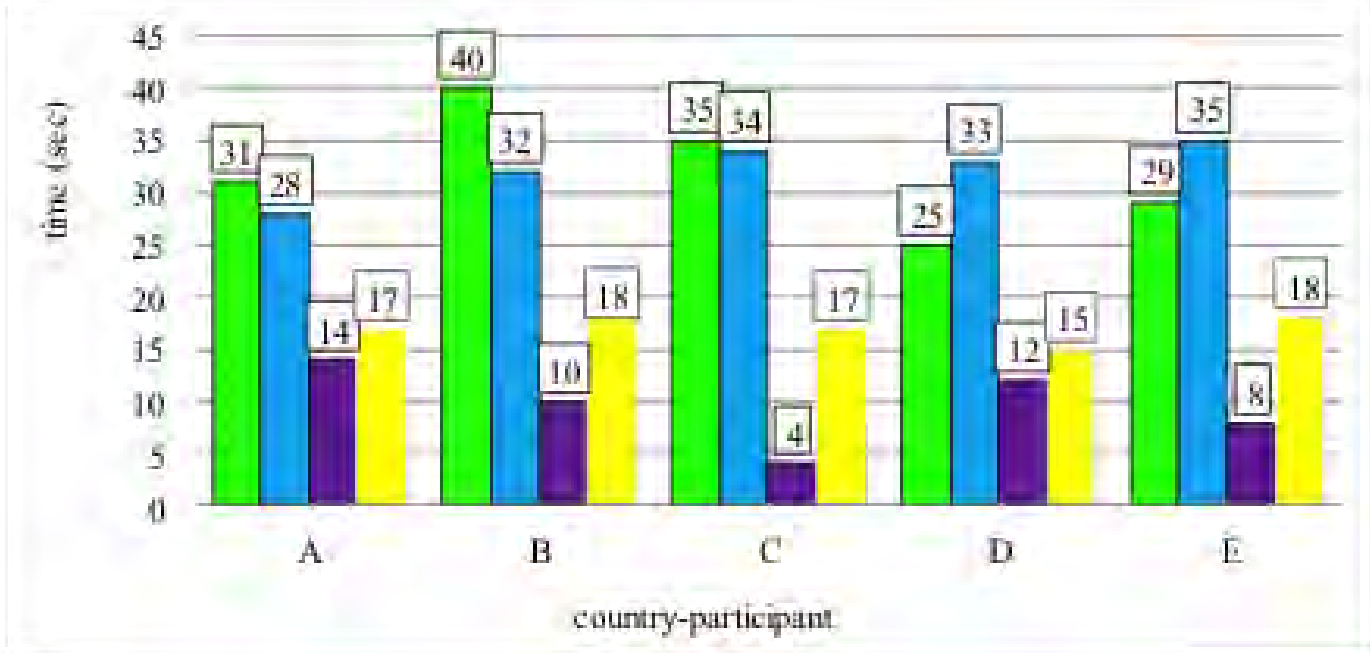

Fig. 7. Indicators of time, spent for fulfillment of individual compositions' with ribbon structural elements, by female gymnasts from countries: A - AZE (Azerbaijan); B - BUL (Bulgaria); C - BLR (Republic of Byelorussia); D - RUS (Russian Federation); E - UKR (Ukraine);

$\square$ Elements of body difficulty (BD);

Elements of apparatus difficulty (AD):

$\square$ Dance tracks $(\mathrm{S} \overrightarrow{\mathrm{*}})$;

Elements of sportsmanship (M);

Elements of risk (R);

site, but with it, she came into angles very deeply. When fulfilling balance penche, she chose closed view in respect to referees' group. It complicated watching of this element by referees.

The final chord of female gymnasts on Olympic site was exercise with ribbon. 4 gymnasts chose rhythmic music, characteristic for Brazil, as accompaniment. Visually, it accelerated the temp of gymnasts' movements. Ganna Rizatdinova fulfilled exercise under accompaniment of rhythmic drumming, exciting Brazil audience by her durable turns and amplitude jumps. Yana Kudryavtseva was exclusion. For her Olympic Games brought a little 
disappointment. The gymnast made mistake in club exercise and lost her Olympic medal in favor of her team mate Margarita Mamun (Olympic champion in 2016). Final performance of Yana Kudryavtseva was under lyrical accompaniment. Exercise was fulfilled "on one breath". The most beautiful passages from one element to another were smoothed by pictures of ribbon. The longest time was spent to dance tracks. It opened all technical skillfulness and elegance of this female gymnast. Body elements were fulfilled with passing to acrobatic elements and elements of dynamic balance (see fig. 7).

In space moving on site Yana Kudryavtseva takes leading positions. She fulfilled diagonal and semicircumference several times. It permitted for her to show all ideal sides of choreographic fitness. Female gymnast Melitina Staniouta made mistake in club exercise and did not become a prize-winner. Ambitious and original dance tracks were fulfilled four times by diagonal and by straight line. The gymnast accented attention at referees' jury and spectators. Gymnasts from Azerbaijan (AZE), Bulgaria (BUL) and Ukraine (UKR) improved the site moving in exercise with ribbon. According to rules, ribbon shall not be stopped and shall not touch the floor even for a moment. That is why gymnasts moved without any stops. They demonstrated movements by diagonal, circumference and by straight line as well as jumps combinations, risk elements and dance tracks (see fig. 8).

\section{Discussion}

At present calisthenics is popularized throughout the world. It is witnessed by increasing of quantity of countries, which cultivate calisthenics and are the members of International Federation of gymnastic. The means of calisthenics are universal: composition, music, apparatuses, dance steps, jumps, turns, balance and waves. These elements permit for female gymnasts to optimally and harmoniously demonstrate the highest coordination, flexibility, jumping [2, 14]. Methodic of calisthenics trainings is headily spread throughout the world. It is facilitated by active and creative work of experienced coaches from Ukraine (UKR), Russian Federation (RUS), Republic of Byelorussia (BLR); as well as of many scientists [6, 10, 15]; specialists from federation and managers. In final competitions of individual multiathlon at OG 2016 high level of sport-technical skillfulness was demonstrated by leaders of world gymnastic: from Russian Federation (RUS), Ukraine (UKR), Republic of Byelorussia (BLR). Female gymnasts from Republic of Korea (KOR), Bulgaria (BUL), Azerbaijan (AZE), Spain (ESP), France (FRA) were their worthy opponents. Below finalists there were also strong gymnasts from USA (USA), Kazakhstan (KAZ), Israel (ISR), Georgia (GEO), Greece (GRE), Japan (JPN) and Uzbekistan (UZB). They demonstrated rather qualified results, which separated them from final of competition by tenth, hundredth and thousandth of point. Such minimal gap illustrates high contest in world calisthenics. To gain victory it is necessary: to demonstrate competition compositions at high sport-technical and artistic level; to have balance psychic state in all competition period [9]. Competition composition is an outcome of coach's and female gymnast's mutual work. Such work shall be directed at

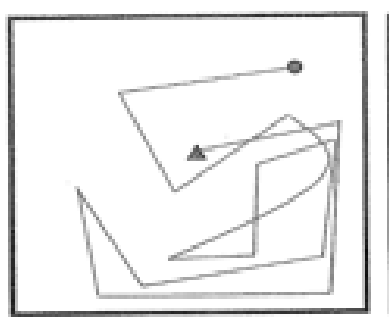

A

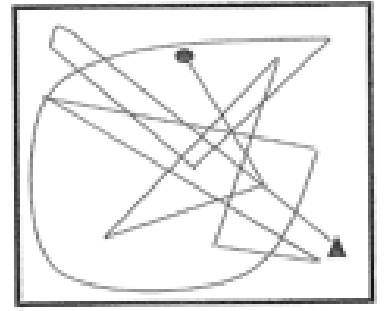

D

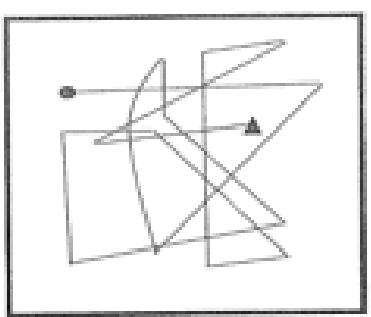

B

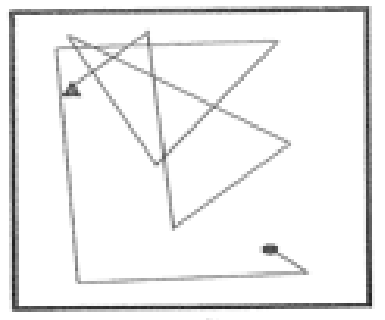

C

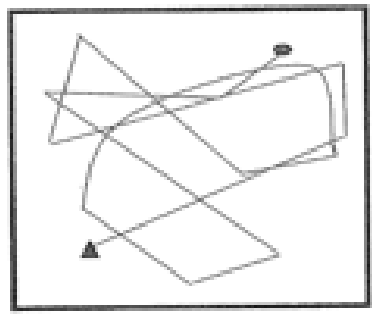

E

Fig. 8. Kinds of female gymnasts' movements on site in competition compositions with ribbon: A - Ribbon composition of Azerbaijan (AZE) gymnast; B - Ribbon composition of Bulgaria (BUL) gymnast; (BUL); C - Ribbon composition of gymnast from Republic of Byelorussia (BLR); D - Ribbon composition of gymnast from Russian Federation (RUS); E Club composition of gymnast from Ukraine (UKR);

\footnotetext{
$\boldsymbol{\Delta}$ - Beginning of exercise;

- End of exercise.
} 
opening sportswoman's potential; her character. Besides, it is necessary to conceal motor actions, which are difficult for a gymnast. For this purpose it is necessary to accentuate elements, which female gymnast fulfills in the best manner. That is why it is important to consider structural elements in building composition: time, spent for body difficulty elements and apparatus difficulty elements; space movements on site. It is also proved by other researches [5]. We have studied structural elements of 4 kinds of multiathlon in 5 elite female gymnasts from: Azerbaijan (AZE,) Bulgaria (BUL), Republic of Byelorussia (BLR), Russian Federation (RUS) and Ukraine (UKR). Our results show that time indicators to large extent are characterized by gymnasts' technical fitness. Ganna Rizatdinova demonstrated high level of space time structural elements. It permitted for the gymnast to master excellent technique of rotations (5 and more rotations). She received high pints for body difficulty. Fulfillment of jumps jete en turnant also brought high points. Gymnast from Azerbaijan (AZE) Marina Durunda demonstrated practically equal indicators of body difficulty and apparatus difficulty. She alternated elements by logical passages and emotional splashes of musical accompaniment. The most masterful manipulation of apparatus was registered in gymnasts from BLR and BUL. Reliable skill in apparatuses' manipulation, perfect coordination of symmetric and asymmetric limbs' movements and beautiful regulation of body positions are the basis of successful demonstration of individual exercises by female gymnasts [2, 12]. In fulfillment of risk and skillfulness elements apparatus came from different directions with minimal contact with hands. Female gymnasts demonstrated apparatus's manipulation without visual control. It added risk in exercise's fulfillment that is required by modern competition rules [16]. Margarita Mamun - Olympic champion, 2016, and Yana Kudryavtseva - silver prize-winner in OG 2016 combined in their compositions masterful manipulation of apparatuses with perfect performance of body difficulty elements. Dance tracks opened all beauty, gracefulness and elegance of these female gymnasts. When building competition composition it is important to consider the chosen pattern and correct time for preparation for elements' fulfillment. Besides, it is necessary to choose correct space view of the demonstrated static and dynamic composition's elements. Deep analysis of individual exercises' space-time structural elements will permit to

\section{References:}

1. Averkovich EP. Kompoziciia uprazhnenij v khudozhestvennoj gimnastike [Composition of exercises in calisthenics], Moscow: VNIIFK; 1989. (in Russian)

2. Boloban VN. Reguliaciia pozy tela sportsmena [Regulation of sportsman's body position]. Kiev: Olympic Literature; 2013. (in Russian)

3. Viner IA. Artistichnost' i puti ee formirovaniia [Artistry and the ways of its formation], Moscow: Men; 2014. (in Russian)

4. Karpenko LA. Khudozhestvennaia gimnastika [Calisthenics], credibly assess competition composition and work out modern methodic of its perfection.

\section{Conclusions}

1. Competition composition of individual exercises in calisthenics consists of body difficulty and apparatus difficulty elements (dance tracks, elements of skillfulness and elements of risk). Procedure of difficulties' fulfillment is free. Difficulties shall be organized and performed logically, smoothly passing in to intermediate movements and elements. Together with idea they shall create composition. It is more than series of difficulties.

2. Analysis of female gymnasts' individual exercises' competition compositions proved their high fitness level. Sportswomen demonstrated high sportsmanship and its important component - performing mastery. OG champion Margarita Mamun, prize-winners Yana Kudryavtseva and Ganna Rizatdinova demonstrated the best possible manipulation of apparatus and body. The transmitted musical accompaniment very sensually and performed elements in the best views by diagonal, semi-circumference and by straight line. Gymnast from Byelorussia (BLR) Melitina Staniouta) performed elements with apparatus at high technical fitness level and emotional reflection of music.

3. In staging competition compositions space-time indicators are accented; they open the best and conceal the worst sides of female gymnasts' fitness. Most of female gymnasts demonstrated combination of body difficulty and apparatus difficulty elements. It also shortens the time of exercise's fulfillment, eliminating duplicated preparation for performance. Thus the time for preparation for element itself is also saved. In this case, for 1'30"' gymnast demonstrates more elements, in good view for referees' assessment. These elements combine with amplitude semi-circumferential, diagonal, straight and polygonal movements. Thus, objective opportunity to visualize idea of competition composition in space is created.

\section{Acknowledgments}

The researches have been fulfilled in compliance with combined plan in the sphere of physical culture and sports for 2016-2020, by topic 2.11 (state registration number 0116U002571).

\section{Conflict of interests}

The authors declare that there is no conflict of interests.
Moscow: Federation of Russia; 2003. (in Russian)

5. Kovalenko YO, Boloban VN. Structural elements of construction of individual and group exercises' competition compositions in calisthenics. Physical education of students, 2016; 20(1): 12-20. doi:10.15561/20755279.2016.0102

6. Miroshnichenko T. Metodika postanovki suchasnikh kompozicij grupovikh vprav u khudozhnij gimnastici [Methodic of staging of modern group exercises' compositions in calisthenics]. Teoriia i metodika fizichnogo vikhovannia i sportu, 2001; 4:11-13. (in Ukrainian) 
7. Morozevich-Shiliuk T. Artistizm akrobatov vysokogo klassa [Artistry of elite acrobats]. Nauka v olimpijskom sporte, 2012;1:74-80. (in Russian)

8. Nachinskaia SV. Sportivnaia metrologiia [Sport metrology], Moscow: Academy; 2008. (in Russian)

9. Omel'ianchik - Ziurkalova OA. Model'noe postroenie kompozicij na vol'nykh uprazhneniiakh s uchetom khoreograficheskoj podgotovlennosti gimnastok [Modeling of free exercises' compositions, considering female gymnasts' choreographic fitness]. Nauka v olimpijskom sporte, 2015;1:63-67. (in Russian)

10.Sosina VIu. Khoreografiia $v$ gimnastike [Choreography in gymnastic], Kiev: Olympic Literature; 2009. (in Russian)

11.Terekhina RN, Kriuchek ES, Medvedeva EN, Zenovka IB. Sovremennyj podkhod $\mathrm{k}$ processu postanovki sorevnovatel'nykh kompozicij v khudozhestvennoj gimnastike [Modern approach to staging of competition composition in calisthenics]. Uchenye zapiski, 2014;8:180185. (in Russian)

12.Tereshchenko IA, Otsupok AP, Krupenya SV, Liauchuk TM, Boloban VN. Coordination training of sportsmen, specializing in sport kinds of gymnastic. Physical education of students, 2015; 19(3): 52-65. doi:10.15561/20755279.2015.0307

13.Boloban Wiktor. Czas reakcji i czas motoryczny w ruchach sportowca. [Time of sportsman's motor reaction]. Pedagogics, psychology, medical-biological problems of physical training and sports, 2009;10:295-301.

14.Zhulkevskaya GV. Gymnastics. Minsk: BGUFK; 2005.

15.Potop V, Grigore W, Marinesku S. Motor Learning gymnastic exercises on the basic of transfer technologies. Science in the Olympic sports, 2012;1:47-57.

16.Rules rhythmic gymnastics. Federation international de gymnastique. Losana; 2012.

17.Ávila-Carvalho L, Klentrou P, da Luz Palomero M, Lebre E. Anthropometric profiles and age at menarche in elite group rhythmic gymnasts according to their chronological age. Science \& Sports. 2013;28(4):172-80.

18.Boloban VN, Tereshchenko IA, Otsupok AP, Krupenia SV, Kovalenko YO, Otsupok AnP. Perfection of coordination with the help of jump exercises on trampoline. Physical education of students, 2016; 20(6): 4-17. doi:10.15561/20755279.2016.0601

19.Dobrescu T, Dobreci LD. Contributions Regarding the Learning of the Specific Motor Content of Artistic Training in the Aerobic Gymnastics. Procedia - Social and Behavioral Sciences. 2014;137:25-31.

20.Mihaela M, Lavinia P. The Impact Induced by the 2009-2012 FIG Code of Points on Artistic Compositions in Rhythmic Gymnastics Group Events. Procedia - Social and Behavioral Sciences. 2014;117:300-6.

\section{Information about the authors:}

Kovalenko Y.O.; http://orcid.org/0000-0001-9417-501X; kovalenkoyana@mail.ru; National University of Physical Education and Sport of Ukraine; Fizkultury str. 1, Kiev, 03680, Ukraine.

Boloban V.N.; http://orcid.org/0000-0001-9119-0695; wboloban@ukr.net; National University of Physical Education and Sport of Ukraine; Fizkultury str. 1, Kiev, 03680, Ukraine.

Cite this article as: Kovalenko YO, Boloban VN. Analysis of Olympic Games (Rio de Janeiro, 2016) participants' individual competition compositions in calisthenics. Pedagogics, psychology, medical-biological problems of physical training and sports, 2017;21(3):111-119. doi:10.15561/18189172.2017.0303

The electronic version of this article is the complete one and can be found online at: http://www.sportpedagogy.org.ua/index.php/PPS/issue/archive

This is an Open Access article distributed under the terms of the Creative Commons Attribution License, which permits unrestricted use, distribution, and reproduction in any medium, provided the original work is properly cited (http://creativecommons.org/licenses/by/4.0/deed.en).

Received: 13.02.2017

Accepted: 25.02.2017; Published: 30.04.2017 